Kalem Eğitim ve İnsan Bilimleri Dergisi 2018, 8(1), 237-265, doi: 10.23863/kalem.2018.102

Makale Gönderim Tarihi:30.11.2016

Makale Kabûl Tarihi:24.08.2017

\title{
İlkokulda Akran İlişkileri: Farklı Başarı Düzeyindeki Dördüncü Sınıf Öğrencileri Arkadaş Özerklik Desteği Hissediyor mu? ${ }^{1}$
}

\author{
Dr. Öğr. Üyesi Şükran CALP* \\ Erzincan Binali Yıldırım Üniversitesi, Eğitim Fakültesi, Sınıf Eğitimi Anabilim Dalı, Erzincan / Türkiye, \\ demetsukran_calp@hotmail.com, ORCID: 0000-0001-6297-9056
}

\section{Arş. Gör. Esra Rabiye KARAMAN}

Recep Tayyip Erdoğan Üniversitesi, Eğitim Fakültesi, Sınıf Eğitimi Anabilim Dalı, Rize / Türkiye, esrarabiye.karaman@erdogan.edu.tr, ORCID: 0000-0002-0203-201X

\section{Feyza ÇAVUŞOĞLU}

Erzincan Binali Yıldırım Üniversitesi, Sosyal Bilimler Enstitüsü, Erzincan / Türkiye, feyzacavusoglu24@gmail.com, ORCID: 0000-0001-7552-5459

\section{$\ddot{O} z$}

Akran ilişkileri, aynı yaş ya da yakın gelişim ve olgunluk düzeyinde olan; benzer geçmiş, değer, yaşantı, hayat tarzı ve sosyal bağlamı paylaşan kişiler arasındaki etkileşimlerin bütünüdür. Akran ilişkilerinde, akran desteği ve güç dengesi, akran yapısını

\footnotetext{
${ }^{1}$ Bu çalışma “İlkokulda Akran İlişkileri: Dördüncü Sınıf Öğrencileri Arkadaş Özerklik Desteği Hissediyor mu?" ismiyle 2016 Uluslararası Sınıf Öğretmenliği Sempozyumu’nda sözlü bildiri olarak sunulmuştur.

* Sorumlu Yazar. Tel: +90 4462240089

(C) 2018 Kalem Eğitim ve Sağlık Hizmetleri Vakfı. Bütün Hakları Saklıdır. ISSN: 2146-5606
} 
şekillendiren önemli unsurlardandır. Bu çalışmanın temel amacı, akademik başarı açısından farklı düzeylerdeki ilkokul dördüncü sınıf öğrencilerinin yakın arkadaşlarından özerklik desteği hissedip hissetmediğini karşılaştırmalı olarak belirlemektir. Bu amaç için öğrenciler akademik başarı düzeylerine göre yüksek ve düşük düzeyde başarılı olarak gruplandırılmıştır. Bir başka ifadeyle ilkokul dördüncü sınıf öğrencilerinin arkadaşlarından özerklik desteği alıp almadığı ve desteklenme noktasındaki algılarının başarı düzeyine göre farklılaşıp farklılaşmadığı belirlenmeye çalışılmıştır. Çalışma nitel araştırma metodolojisine göre desenlenmiş olup bir durum çalışması niteliğindedir. Veri toplama tekniği olarak "yüz yüze görüşme"ler yapılmış, öğrencilere çizdirilen resimler de "doküman incelemesi" tekniği kapsamında değerlendirilmiştir. Katılımcılar ölçüt örnekleme yöntemiyle seçilmiştir. "İlkokul dördüncü sınıfta olmak" ve "yüksek ya da düşük düzeyde başarılı olmak" katılımcıların belirlenmesindeki ölçütlerdir. Bulgulara göre gerek düşük başarılı gerekse yüksek başarılı öğrencilerin tamamına yakını, arkadaşları tarafından verilecek özerklik desteğini arzu ettiklerini, böyle bir desteğin hoşlarına gideceğini vurgulamıştır. Başarısı yüksek öğrencilerin büyük çoğunluğu, okulda kendi kararlarını kendilerinin alması noktasında özgür hissetmekte; ancak bu konuda arkadaşlarından yeterince destek alamamaktadır. Özerklik hissetme durumu düşük başarılı öğrencilerde tam tersidir. Bu öğrencilerin yarıdan fazlası okulda özerkliği hissetmemekte ve kararlarında arkadaşlarının etkisi görülmektedir. Sonuç olarak, gerek başarılı öğrenciler gerekse akademik başarı açısından geride kalan öğrencilerin, arkadaşları tarafından özerkliğinin desteklenmesi ve teşvik edilmesi duygusunu arzu edilen ölçüde yaşamadığı tespit edilmiştir. Bu durum ülkemizde "arkadaş özerklik destekleyiciliğiı" yle ilgili bir farkındalık olmadığı şeklinde yorumlanabilir. Bu çalışma böyle bir farkındalığın kazandırılması açısından önemli görülmektedir.

Anahtar Kelimeler: Özerklik; Özerlik desteği; Akran; Yakın arkadaş; Akademik başarı; İlkokul.

\title{
Peer Relations in Elementary School; Do Fourth Grade Students with Different Achievement Levels Feel Peer Autonomy Support?
}

\begin{abstract}
Peer relations is a whole of interactions among people that are at same age or have close developmental and maturity level and share similar
\end{abstract}


backgrounds, values, life, lifestyles and social context. Individual characteristics, peer support and power balance are important factors in peer relationships. In education literature, the issue of autonomy supportiveness in peer relations is newly studied. The main purpose of this study is to comparatively determine whether fourth-grade elementary school students with different achievement levels feel autonomy support from close friends. For this purpose, students are grouped as high and low performance according to academic achievement levels. This study was designed as case study with qualitative research method. Face-to-face interview is used as data collection method. Participants are selected by criterion sampling method. "Being fourth-grade primary school student" and "being low and high performance" are the criteria for selection of participants. According to findings almost all students, whether they are low and high performance, emphasize that they urge autonomy support from their friends and would like this kind of support. while almost all the high-performance students feel confident to take their own decision, they feel that they do not get enough support from their friends. Feeling autonomy in low performance students is exact opposite. Consequently, it is determined that both successful students and the students who are back in terms of academic achievement do not feel the emotion of supporting autonomy and encouragement in desired level. This finding can be interpreted as there is not any awareness about "autonomy support from friend" in our country.

Keywords: Autonomy; Autonomy support; Peer; Close friend; Academic achievement; Elementary school.

\section{Extended Summary}

\section{Purpose}

Peer relations is a whole of interactions among people that are at same age or have close developmental and maturity level and share similar backgrounds, values, life, lifestyles and social context. Individual characteristics, peer support and power balance are important factors in peer relationships. In education literature, the issue of autonomy supportiveness in peer relations is newly studied. The main purpose of this study is to comparatively determine whether fourth-grade elementary school students with different achievement levels feel autonomy supportiveness from close friends. For this purpose, students are grouped as high and low performance according to academic achievement levels. In the other words, it is studied that whether fourth-grade elementary school students take autonomy support and their perceptions of 
such differentiate according to level of academic achievement. Predicting whether taking autonomy support has something to do with academic achievement was considered as a secondary purpose. Therefore, academic achievement variable is preferred as benchmark.

\section{Method}

This study was designed as case study with qualitative research method. Face-to-face interview method is used as data collection method. Pictures that students drew were also evaluated within the scope of document review technique.

Participants are selected by criterion sampling method. "Being fourthgrade primary school student" and "being low and high performance" are the criteria for the determination of participants. Reason why fourth grade students were selected as participant in the study is that we felt they would be able to understand and experience the concept autonomy support the participants of the study consisted of 88 fourth-grade elementary students studying at high and low performance schools in Erzincan and their classroom teachers. Schools are grouped as high and low performance according to academic achievement levels. In determining the academic achievement level of the schools, academic achievement rankings in the tests that Directorate of National Education declare and carried out across the province was taken into consideration. Besides, by speaking with the classroom teachers in the aforementioned schools, the most successful students in the "successful" category and the unsuccessful students who study in the school which is "underachievement" category were preferred.

Data were obtained by face-to-face interview. A semi-structured form is used during interviews. Students are also wanted to draw pictures that describe their friend's supporting autonomy or draw a picture telling an incident about their autonomy support. The students also were told preferably to write a composition.

Interview questions were asked to students with reference to precedent by considering their developmental period. After each sample story the questions put to students are such as to explore the following basic questions:

1. Do you need the autonomy support and do you want such a support?

2. How much are you free when taking your own decision in the school? In the topics about school do your friends support taking your own 
and free decisions?

3. Do your friends encourage you to be yourself?

4. Do your friends accept and respect your emotions and ideas even if your emotions and ideas different from them?

Although trying to separate questions by using the sample stories, it was observed that students give similar responses to different questions. In this context, many questions are in the position of interwoven.

\section{Result}

According to findings almost all students who are both low and high performance emphasize that they urge autonomy support from their friends and they would like this kind of support.

According to findings, while almost all of the high performance students feel free to take their own decision, in this issue they can't take enough support from their friends. The situation of feeling autonomy is exact opposite for low performance students. More than half of these students do not feel autonomy in the school and impacts of their friends are seen in their own decision. This finding, can be interpreted as even if students do not take enough support from their friends, the situation of feeling autonomy in favor of high performance students is related with level of academic achievement.

The findings has revealed the result that students have difficulty of being themselves, do not be supported about being like themselves, further they are unaware of any existing situation like this. Because the students mostly want to earn sympathy or love their friends, they are tend to act like them. This situation is much more dominant in the low performance students. About half of the students who were met in the high category schools are not confronted by any intervention and it is understood that they are freer with the point of being themselves. In schools that are in the category of low performance, big majority of the students who were met are in direction of their friends and thus it is understood that they are inefficient about being unique.

Similarly the findings show that ideas and emotions of fourth-grade students who study in high performance schools are substantially accepted and respected by their friends. The students who study in low performance schools experience much less of this situation of being respected. Also teachers used 


\section{Dr. Öğr. Üye. Şükran CALP / Arş. Gör. Esra R. KARAMAN / Feyza ÇAVUŞOĞLU}

the statements which support students' sayings. Especially in low performance schools, autonomy support is scarcely any.

\section{Discussion and Conclusion}

Consequently, it is determined that both successful students and the students who are back in terms of academic achievement do not live the emotion of supporting autonomy and encouragement in desired level. This situation can be interpreted as there is not any awareness about "autonomy support from friend" in our country. Although high performance students state that they feel autonomy support partially, this achievement is not seen enough for autonomy support which is critized by many positive output as being good and high motivation. In the light of these results, teachers should lead in the point of friends support one another in academic autonomy and should act and encourage autonomy support. The first thing to do in order to form student-based class environment and have the right to comment on his own learning is given an opportunity for the students to participate in decision making mechanism in the dimensions planning, learning and evaluation.

\section{Giriş}

Akran ilişkileri, aynı yaş ya da yakın gelişim ve olgunluk düzeyinde olan; benzer geçmiş, değer, yaşantı, hayat tarzı ve sosyal bağlamı paylaşan kişiler arasında karşılıklılık ve devamlılık gösteren etkileşimlerin bütünüdür. Bebeklik ve erken çocukluk dönemlerinde ailenin güven veren ve koruyucu ortamında yaşayan çocuklar, yaşları büyüdükçe farklı ortamlarda akranları ile bir arada olmaya ve birlikte zaman geçirmeye başlamaktadırlar. Akran ilişkileri, çocuğun gelişiminde önemli bir yere sahiptir. Akran ilişkilerinin çocuklara sunduğu yaşantı benlik bilincinin oluşumuna imkân sağlar, kendileri hakkında bir yargıya varırlar. Böylece sosyal rollerine, konumlarına ve cinsel kimliklerine uygun davranmayı öğrenirler (Gülay, 2009).

Rodkin ve Hodges (2003), akranların oluşturduğu bu ilişki atmosferine "akran ekolojisi (peer ecology)" ismini verir ve onlara göre akran ekolojisi çocukların sosyalleştiği, birbirlerinden etkilendiği ve birbirlerini etkilediği mikro sisteminin bir parçasıdır. Yetişkinler bu sisteme dâhil değildir; fakat sistem yetişkinlerden etkilenir.

Arkadaşlık kurmak, çocuk gelişiminde aile üyelerinden daha farklı bir role sahiptir. Arkadaş ilişkileri, aile ilişkileri kadar yoğun ve uzun süreli ol- 
mamasına rağmen, daha eşitlikçi olma eğilimindedir ve sosyalleşme için firsatlar sunar. Sosyal yeterlik, etkili ve sosyal olarak kabul edilebilir bir ilişki biçimine ya da "bir yandan insanlarla olumlu ilişkileri sürdürürken aynı zamanda sosyal iletişimde kişisel hedefleri başarma yeteneği"ne atıfta bulunur (Rohrbeck, 2003). Piaget (1932) ve Sullivan (1997) gibi bazı gelişim kuramcıları, arkadaş ilişkilerinin gelişiminin sosyal yeterlik, sosyalleşme, öz yeterlik ve adalet duygusunun gelişimi için önemli olduğunu ileri sürmektedir.

Akran ilişkileri, çocukların sosyal gelişimlerinin yanı sıra psikolojik, duygusal ve bilişsel gelişimleri açısından da oldukça önemlidir. Bir grubun üyesi olma, aidiyet ya da ilişkili olma ihtiyacı, sosyal çevre ve özellikle de arkadaşlar tarafindan kabul görme ve dostluk kurmayı kapsamakta ve Maslow (1970) tarafindan beş temel ihtiyaçtan birisi (friendship and belonging) olarak nitelendirilmektedir. Akran ilişkileri ve arkadaşlık, bireyin bütün yaşamı boyunca kuracağı ilişkilerin yapıtaşını oluşturacak faktörlerdendir.

Akran ilişkileri, çocuğun bireysel özellikleri, aile, kültür, stres ve sosyal destek gibi birçok konudan etkilenmekle birlikte araştırmacılar, çocukların sosyal becerileri ve sosyal yeterliliği üzerinde odaklanmışlardır. Sosyal beceri, çocukların sosyal görevleri tamamlama ve sosyal başarıya erişmesine yardım eden davranışlar olarak tanımlanır. Böyle davranışlar, göz teması kurma ve tanışma gibi basit gözlenebilen davranışları ve diğerlerinin duygu ve düşüncelerini anlama ya da olumlu ve olumsuz hislerini uygun bir dille nas1l ifade edeceğini bilme gibi kompleks becerileri kapsar (Rohrbeck, 2003). Kendini tanıtmak, konuşmak ve bir gruba katılmak gibi beceriler, ilköğretim çağındaki çocukların sahip olması beklenen sosyal beceriler arasında kabul edilmektedir (Bacanl1, 1999).

Birçok araştırma çocukların akran ilişkilerinin, onların okula uyum davranışına ve gelişimine katkısını incelemiştir. Bu araştırmalarda, akranlar arasındaki zayıf ilişkiler ya da ilişkisizlik, okul yıllarındaki kaygı, yalnızlık, depresyon, devamsızlık gibi problemler ile okula uyum ve başarı motivasyonunun önemli bir yordayıcısı olarak bulunmuştur (Asher ve Parker, 1989, DeRosier, Kupersmidt ve Patterson, 1994; Hymel, Rubin, Rowden ve LeMare, 1990; Kochenderfer ve Ladd, 1996; Ladd, Kochenderfer ve Coleman, 1996; Wentzel ve Asher, 1995). Ladd (1990), arkadaşlık ve akran kabulünün, özellikle okul öncesi dönemdeki çocuklarda okulla ilgili olumlu tutum geliştirme, uyum ve okul performansını etkilediğini ileri sürmektedir. Aynı araştırmada, akranları tarafından reddedilen çocukların, okul hakkında olumsuz algılama, 


\section{Dr. Öğr. Üye. Şükran CALP / Arş. Gör. Esra R. KARAMAN / Feyza ÇAVUŞOĞLU}

okulu reddetme ve yıl boyunca süren akademik başarı düşüklüğü gibi yaşantılara girdikleri gözlenmiştir. 1950'lerden bu yana yapılan çalışmalar göstermektedir ki akran kabulü ya da akran reddi, akademik güçlükler ve okulu b1rakma davranışıyla yakından ilişkilidir (Buhs, Ladd ve Herald, 2006; Ladd, Herald ve Andrews, 2006).

Akran ilişkilerindeki arkadaşlığın niteliği, çocukların duygusal iyi olma ve psikolojik uyumlarının önemli bir yordayıcısı olarak görülmektedir. Yakın arkadaşlık ve akran kabulü (peer acceptance), beraberinde sosyo-duygusal başarıyı getirirken, akran reddi (peer rejection) ve saldırganlık, çocuklarda uyumsuzluk riskini artırmaktadır. Zayıf akran ilişkileri, zayıf sosyal beceriler, saldırganlık ve empati eksikliğiyle ilişkilidir (Bagwell, Newcomb, Bukowski, 1998; Parker ve Asher, 1993; Parker, Rubin, Price ve DeRosier, 1995).

Akran ilişkilerinde, akranların sosyal becerileri, saldırgan ya da dostça yaklaşımları gibi birtakım bireysel özellikleri önemlidir: Bireysel özellikler yanında akran desteği ve güç dengesi, akran yapısını şekillendiren diğer unsurlardandır (Song, 2006). Akran ilişkilerinin, çocuğun gelişimine katkısı göz önüne alındığında, arkadaş ilişkilerinde özerklik destekleyici-liğin etkileri araştırılır olmuştur. Bu araştırmalar, bir akran ya da arkadaş yoluyla desteklenen özerkliğin, özerk motivasyonu, performansın kalitesini ve psikolojik sağlığ1 geliştirdiğini ortaya koymuştur (Baard, Deci ve Ryan, 2004; Deci, LaGuardia, Moller, Scheiner ve Ryan, 2006; Deci ve Ryan, 2014; Doeselaar, 2015; Giessen, Branje ve Meeus, 2014; Ruzek, Hafen, Allen, Gregory, Mikami ve Pianta, 2016; Soenens, Vansteenkiste, Goossens, Duriez ve Niemiec, 2008; Williams, Grow, Freedman, Ryan ve Deci, 1996).

Eğitim alanyazınında, akran ilişkilerinin kalitesi ya da niteliğinin, çocuğun hayatındaki önemi ve çocuğun gelişimine katkısı üzerine birçok çalışma yapılmıştır. Ancak arkadaş ilişkilerindeki özerklik destekleyiciliği konusu, üzerinde yeni yeni durulan bir husustur. Akranlar arasındaki özerklik desteği, bir arkadaşın diğerlerinin bakış açısını ve özgür tercihlerini kabul etmesi, onlara karşı duyarlı olması ve onların kendi kendine karar vermesini cesaretlendirmesi olarak tanımlanır.

Özerklik, gerek aile ortamında gerek akran ilişkilerinde gerekse öğretme-öğrenme ortamında karşılanması gereken bir ihtiyaçtır. Öğretmen, aile, arkadaşlar gibi sosyal çevre elemanlarından alınan özerklik desteğinin, özerk davranış sergileme, işe kendini verme ve öğrenmenin kalitesini nasıl artırabi- 
leceğine dair bir gerekçe sunmaktadır. Özerklik hissi için en önemli kaynaklardan biri aile, öğretmen, arkadaş gibi sosyal çevre elemanlarının özerkliği destekleyici tutumlarıdır. Bireyin özerklik hissedebilmesi ve özerk davranabilmesi, çevrenin özerklik desteğiyle yakından ilişkilidir. Özellikle akranlar ya da arkadaşlar, bireyin tüm yaşamı boyunca kuracağı ilişkilerin yapıtaşını oluşturma noktasında önemli bir rol üstlenmiştir.

Akranlar arasındaki özerklik desteği, bir arkadaşın diğerlerinin bakış açısını ve özgür tercihlerini kabul etmesi, onlara karşı duyarlı olması ve onların kendi kendine karar vermesini cesaretlendirmesi olarak tanımlanır. Özerklik desteğiyle ilgili yapılan çalışmaların birçoğunda otorite ya da uzmanlık noktasındaki farklılıkları kapsayan ilişkiler üzerinde durulmuştur. Bir başka ifadeyle, öğretmen, aile, takım kaptanı, yönetici ya da aile gibi otoritelerin özerklik destekleyiciliği araştırılmıştır ve bu araştırmalar göstermiştir ki bir otorite figürü kişiye özerklik sağladığında, o kişi motivasyon, performans ve iyi olmadaki gelişmeyi tecrübe eder (Deci, Ryan, Gagne, Leone, Usunov ve Kornazheva, 2001)

Otorite farklılıklarındaki değişikliği kapsayan ilişkilerin en önemli özelliği “ortaklık (mutuality)” eksikliğidir. Fakat yakın arkadaşlık ya da romantik ilişkiler gibi akran ilişkilerinde, söz konusu bu ortaklığın olması muhtemeldir. Akran ilişkilerindeki bu ortaklık, özerklik destekleyiciliğinde kilit bir öneme sahiptir. Deci ve diğerleri (2006), arkadaşından yüksek seviyede özerklik desteği alan kişinin, bundan büyük oranda faydalanacağını iddia etmektedir. Çünkü onlar duygusal olarak önemli yaşantıları paylaşacaklar ve birbirlerine daha güvenli bağlanacaklardır.

Bir arkadaştan özerklik destekleyiciliği hissetmek ya da benzer olarak ona özerklik destekleyici davranmak, ihtiyaç doyumu için önemli bir kaynaktır. Kişinin ona özerklik sağlayan bir arkadaşa sahip olduğu için "yeterlilik"; arkadaşı tarafından dikkate alınma ya da önemsenme duygusunu tecrübe ettiği için "iliş̧kili olma" ve kendisi için önemli olan şeyleri yine kendi iradesiyle, gönüllü ve özgürce yaptığı için "özerklik" hissetmesi muhtemeldir (Deci ve ark., 2006).

Arkadaştan alınan özerklik desteği, temel psikolojik ihtiyaçların tatmininde karşılıklılık sağladığı için ilişkinin kalitesi ve iyi olmayla da ilişkilidir. Özerkliğin desteklendiği ilişkilerde, ilişkinin kalitesi ya da niteliğinin gelişme olasılığ1 yüksektir (La Guardia, Ryan, Couchman ve Deci, 2000). Hodgins, Koestner ve Duncan (1996), yaptıkları bir çalışmada, davranışlarında daha 
özerk olan bireylerin ilişkilerinin daha olumlu ve samimi olduğu bulgusuna ulaşmıştır. Yani özerklik, daha doyurucu kişiler arası ilişkiyi de beraberinde getirmektedir.

\section{Çalışmanın Amacı}

$\mathrm{Bu}$ çalışmanın temel amacı, akademik başarı açısından yüksek ve düşük düzey olmak üzere iki grupta yer alan ilkokul dördüncü sınıf öğrencilerinin yakın arkadaşlarından özerklik desteği hissedip hissetmediğini karşılaştırmalı olarak belirlemektir. Bir başka ifadeyle ilkokul dördüncü sınıf öğrencilerinin arkadaşlarından özerklik desteği alıp almadığı ve desteklenme noktasındaki algılarının başarı düzeyine göre farklılaşıp farklılaşmadığı belirlenmeye çal1ş1lmıştır. Karşılaştırma ölçütü olarak "akademik başarı" değişkeninin tercih edilmesinde, özerklik desteği alma ya da almama durumunun, başarıyla ilişkisi olup olmadığını yordamak, ikincil bir amaç olarak düşünülmüştür.

\section{Çalışma Deseni}

\section{Yöntem}

Çalışma nitel araştırma metodolojisine göre desenlenmiş olup bir durum çalışması niteliğindedir. "Akran özerklik desteği” bu çalışmanın temel inceleme konusudur. Veri toplama yöntemi olarak "yüz yüze görüşme" tekniği kullanılmıştır. Öğrencilere çizdirilen resimler de "doküman incelemesi" tekniği kapsamında değerlendirilmiştir.

\section{Çalışma Grubu}

Çalışmaya Erzincan il merkezi sınırları içindeki düşük ve yüksek başar1lı okullarda öğrenim gören 88 ilkokul dördüncü sınıf öğrencisi ve onların sınıf öğretmenleri katılmıştır. Görüşülen sınıf öğretmeni sayısı dokuzdur ve öğretmenler çalışmaya gönüllü katıldıklarını beyan etmişlerdir. Görüşme yapmak istemediğini beyan eden beş sınıf öğretmeni çalışmanın kapsamı dışında tutulmuştur.

Katılımcılardan öğrenciler, ölçüt örnekleme yöntemiyle seçilmiştir. "İlkokul dördüncü sınıfta olmak" ve "yüksek ya da düşük düzeyde başarılı olmak" katılımcıların belirlenmesindeki iki ölçüttür. Katılımcıların oluşturulmasındaki iki ölçütten birinin "sınıf düzeyi" olmasında içinde bulunduğu bilişsel gelişim dönemi olarak özerkliği anlamaya ve yaşamaya en yakın ilkokul kademesinin "dördüncü sınıflar" olduğu inancı etkili olmuştur.

Okullar başarı düzeylerine göre düşük ve yüksek başarılı olarak grup- 
landırılmıştır. Okulların başarı düzeyinin belirlenmesinde millî eğitim müdürlüğünün ilan ettiği il genelinde yapılan sınavlardaki akademik başarı sıralamaları dikkate alınmıştır. Ayrıca söz konusu okullardaki sınıf öğretmenleriyle de görüşülerek "başarılı" kategorisindeki okullardan en başarılı ve "düşük başarılı" kategorisindeki okullardan akademik başarı açısından düşük seviyeli öğrenciler tercih edilmiştir.

Çalışma kapsamında öğrencilerin söylediklerinden alıntılar yapılırken düşük düzeyde başarılı öğrenciler için "DBÖ...." kod adı, yüksek düzeyde başarılı öğrenciler için "YBÖ..." kod adı kullanılmıştır. Öğrencilerin söyledikleri aktarılırken bu kod adlar, öğrenci veri giriş sırasına göre numaralandırılarak kullanılmıştır. Öğretmenlerin söylediklerinden alıntılar yapılırken düşük başarılı öğrencilerin öğretmenleri için "Öğretmen DB...” kod adı, yüksek başarılı öğrencilerin öğretmenleri için "Öğretmen YB...” kod adı kullanılmıştır.

\section{Veri Toplama Araçları}

Veriler, yapılan yüz yüze görüşmeler ve çizdirilen resimler yardımıyla elde edilmiş olup görüşmeler sırasında yarı yapılandırılmış bir görüşme formu kullanılmıştır. Görüşmeler tamamlandıktan sonra öğrencilerden arkadaşlar1nın özerklik destekleyiciliğini betimleyen ya da onların özerklik destekleyiciliğine ilişkin yaşadıkları bir olayı anlatan resimler çizmeleri istenmiştir. Çalışma kapsamında resimler, içinde bulundukları gelişim dönemi itibariyle öğrencilerin kendilerini resimle daha iyi ifade edebileceği düşüncesinden hareketle kullanılmıştır. Resimler ayrıca araştırmacılar için bir nevi katılımeı teyidi özelliğini de taşımaktadır. Öğrencilerin sözlü beyanlarında ifade etikleri durumları yaşayıp yaşamadıkları ya da hangi durumlarda yaşadıklarını anlamada resimlerin önemli katkısı olmuştur. Öğrencilere tercihen kompozisyon yazabilecekleri de söylenmiştir. Ancak kompozisyon yazmayı tercih eden olmamıştır.

Gerek öğrenciler gerekse öğrencilerin sınıf öğretmenleriyle yapılan görüşmeler okul ortamında çeşitli yerlerde, teneffüs zamanlarında ve yüz yüze yapılmıştır. Öğrencilerle yapılan yüz yüze görüşmeler ortalama 30-35 dakika, öğretmenlerle yapılan yüz yüze görüşmeler ise ortalama 10-15 dakika sürmüştür. Resim çizmeleri için öğrencilere istedikleri kadar zaman verilmiştir.

Görüşme soruları öğrencilere gelişim dönemleri dikkate alınarak örnek olaylardan hareketle yöneltilmiştir. Her bir örnek olaydan sonra öğrencilere yöneltilen sorular aşağıdaki temel soruları araştırır niteliktedir. 
1. Özerklik desteğine ihtiyacın var mı, böyle bir desteği ister misin?

2. Okulda kendi kararlarını alırken ne kadar özgürsün? Arkadaşların okulla ilgili konularda özgür ve kendi tercihlerine göre kararlar alabilmeni destekler mi?

3. Arkadaşların seni kendin olman için cesaretlendirir mi?

4. Arkadaşların, duygu ve düşüncelerin, kendilerininkinden farklı olsa bile senin duygu ve düşüncelerini kabul edip saygı duyar mı?

Aşağıda bu temel soruların öğrencilere hangi örnek olaylar kullanılarak yöneltildiği açıklanmıştır. Birinci ve ikinci sorular için iki, üçüncü soru için üç ve dördüncü soru için bir örnek olay hazırlanmıştır. Öğrencilerin örnek olayı anlamadığ 1 durumlarda alternatif örnek olay işe koşulmuş ya da soru farklı şekillerde yeniden ifade edilmiştir.

1. Özerklik desteğine ihtiyacın var mı, böyle bir desteği ister misin?

Örnek olay 1: Öğretmeninin verdiği ödevi değil de kendi istediğin etkinliği yapabildiğini, buna izin verildiğini düşün ya da çalışmak istediğin arkadaşlarını kendinin seçtiğini düşün. Arkadaşlarının ve öğretmeninin seninle son derece samimi, güleryüzle ilgilendiğini düşün. Arkadaşlarının sen ödevini yaparken senin yanında olduğunu ve ödevini çok iyi yapabileceğinle ilgili seni cesaretlendirdiğini düşün. Örneğin arkadaşlarından birinin sana "Sen bu işte çok iyisin Ali, Ayşe, Fatma..., bu konuda sana çok güveniyorum. Öğretmene verdiğin cevaplarl çok beğeniyorum" dediğini düşün. Böyle bir şey hoşuna gider mi? İster misin? Niçin?

Örnek olay 2: Okulda arzu ettiğin etkinlikleri yapmak, mesela istediğin kitabl, istediğin yazarı okumak, istediğin şiiri ezberlemek, bir tiyatro etkinliğinde istediğin rolü almak, istediğin arkadaşınla grup etkinliği yapıyor olmak... hoşuna gider mi? Yoksa bunları biri senin adına karar verse daha mı çok mutlu olursun?

2. Okulda kendi kararlarını alırken ne kadar özgürsün? Arkadaşların okulla ilgili konularda özgür ve kendi tercihlerine göre kararlar alabilmeni destekler mi?

Örnek olay 1: Teneffüse çıktınız. Bahçede birçok sevdiğin kişi var. Kiminle oynayacağına, kiminle arkadaşlık edeceğine nasıl karar verirsin? Arkadaşların sana karışır mı? Kararlarını özgürce vermen için seni rahat mı 
bırakır yoksa kendi istediklerini yapman için seni zorlar mı? Iç̧inden geldiği gibi davranmana izin veriliyor mu? Arkadaşların seni etkiler mi?

Örnek olay 2: Serbest etkinlik zamanındasınız. Öğretmenin istediğinizi yapabileceğinizi söyledi. İstediğini yapabiliyor musun? Arkadaşların seni yönlendiriyor mu?

3. Arkadaşların seni kendin olman için cesaretlendirir mi?

Örnek olay 1: Öğretmenin bir grup çalışması yapacağınızı ve deprem konusuyla ilgili bir sunu hazırlayacağınızı söyledi. Arkadaşların grupta senin istediğin görevi almana nasıl tepki verir? Senin kendi cümlelerinle, kendin gibi davranarak konuyu anlatman onların hoşuna gider mi?

Örnek Olay 2: Öğretmenin kulüp seçimi yapılacă̆ını ve herkesin kendisine uygun, kendini mutlu hissedeceği bir kulübü seçmesini istedi. Arkadaşların senin istediğin kulübe katılmana nasıl tepki verir?

Örnek Olay 3: "Bak Ayşe, Fatma, Ali kendin gibi davran, kendi düşüncelerini paylaş, başkalarından etkilenmeden, onlart taklit etmeden kendin ol" diyen arkadaşın var mı? Yoksa daha önce hiç kendin gibi olmakla ilgili cesaretlendirmediler mi seni? "Yanlış da hatalı da olsa belki de düzeltebilmek için sırf senin düsüncen diye o duygu ya da düşünceyi paylaşmalısın." diyen oldu mu? "Sen nasıl düşünüyorsun? Senin fikrin nedir?" diye sorarlar mı arkadaşların?

4. Arkadaşların, duygu ve düşüncelerin, kendilerininkinden farklı olsa bile senin duygu ve düşüncelerini kabul edip saygı duyar mı?

Örnek olay: Öğretmen grup olarak Atatürk'ü anlatan bir program hazırlamanızı istedi. Sen resimlerin daha bol kullanılması gerektiğini, böyle daha etkili bir sunum olacă̆ını söylüyorsun ama arkadaşların Atatürk'ü şiirler ve şarkılarla anlatmanın daha doğru olacă̆ını düşünüyor. Böyle bir durumda ne olur? Arkadaşların senin görüşüne saygı gösterip kabul eder mi? Yoksa "Hayır saçmallyorsun, sen değil ben haklıyım. Senin düşüncen yanlış. Benim dediğim olacak." gibi dayatmalara mı başvurur?

Öğretmenlere yöneltilen sorular ise öğrencilerinin birbirinin özerk davranmasını destekleyip desteklemediğiyle ilgili gözlem ve düşüncelerine yönelik olmuştur. Temelde aynı ve tek bir noktayı irdelemekle birlikte öğrencilerin özerklik destekleyiciliğine yönelik sorular öğretmenlere farklı ifadeler ve ör- 
nek olaylarla sorulmuştur. Soruların örnek olaylarla çeşitlendirilmesinde, öğretmenlerin özerklik ve özerklik desteği konusuyla ilgili çok fazla bilgiye sahip olmamaları etkili olmuştur. Aşağıda öğretmenlere yöneltilen sorular yer almaktadir.

- Öğrencilerinizin birbirinin kararlarına saygı duyduğunu, birbirinin kişisel alanına müdahale etmeyip anlayışı davrandığını gözlemliyor musunuz?

- Öğrencilerinizin okulla ilgili konularda ya da genel olarak birbirini yüreklendirdiğini, motive ettiğini gözlemliyor musunuz?

- Öğrencilerinizin ağzından birbirleri için hiç “Ayşe, Fatma, Ali... sen bu konuda çok iyisin, seni takdir ediyorum." ya da "Ayşe, Fatma, Ali... sen bunu yapabilirsin, kendine güven." şeklinde cümleler sarf ettiklerini duyuyor musunuz? Böyle bir gözleminiz var mı?

\section{Geçerlik, Güvenirlik, İnandırıcılık}

Araştırmanın geçerliğini artırmak amacıyla soru formu hazırlanırken alan yazın incelenmiş ve uzman görüşü alınmıştır. Verilerin analizinde konunun açıklanabilecek kadar kapsamlı ve öz olmasına dikkat edilmiş, bu aşamada da uzman görüşüne başvurulmuştur. Analiz araştırmacılar tarafindan ayrı ayrı yapıldıktan sonra sonuç benzeşen ve farklılaşan yönleriyle yeniden ele alınmış ve analiz sonrası oluşan kod, tema ve kategoriler, Sınıf Eğitimi doktoralı bir uzman tarafından kontrol edilmiştir. Ayrıca çalışmanın inandırıc1lığı ve güvenirlik için öğretmen adaylarının ifadelerinden doğrudan alıntılara yer verilmiştir.

Öğrenci düşünceleri, örnek olaylardan hareketle ortaya çıkarılmaya ça1ış1ldığı için analiz öncesi öğrencilerden bazılarına tekrar dönülmüş söz konusu düşüncenin araştırmacılar tarafından doğru anlaşı1ıp anlaşılmadığına dâir geri bildirimler alınmıştır. Çalışmada bu yönüyle katılımcı teyidi sağlandığından söz edilebilir.

Katılımcılardan öğretmenlere, etik kuralları gereği gönüllü olup olmadıkları sorulmuş ve sözlü beyanları doğrultusunda çalışmaya dahil edilmişlerdir. Öğrenciler için il millî eğitim müdürlüğünden alınan izin yazısı esas alınmiştır. 


\section{Verilerin Analizi}

Verilerin analizinde çalışmanın doğasına ve soruların içeriğine daha uygun olduğu gerekçesiyle betimsel analiz kullanılmıştır. Sorular, örnek olaylar kullanılarak ayrıştırılmaya çalışılmasına rağmen öğrencilerin farklı sorulara benzer tepkiler verdiği gözlenmiştir. Bu bağlamda birçok soru iç içe girmiş durumdadır. Analiz için öğrencilere yöneltilen sorular, çalışmanın kategorilerini oluşturmuştur. Bu kategoriler aşağıdaki gibidir:

\section{Arkadaş Özerklik Desteğine Duyulan İhtiyaç}

Bu kategoride öğrencilere "Özerklik desteğine ihtiyacın var m1, böyle bir şeyi ister misin?” sorusu yöneltilmiştir. Yüksek başarılı kategorisindeki öğrencilerden sadece biri hariç diğerleri arkadaşlarından alacakları özerklik desteğine duyduğu ihtiyacı dile getirmiştir. Aşağıda söz konusu soruya ilişkin doğrudan alıntılara yer verilmiştir.

YBÖ3: “Arkadaş desteği isterim. Kendi desteğime arkadaşlarımın desteği eklenirse güven duyarım. Gurur duyarım. Mutlu olurum."

YBÖ5: "Arkadaşlarım tarafindan cesaretlendirilmek istemem. Kaybedersem üzülürüm, arkadaşlarım üzülür. Beni annem, babam cesaretlendirsin."

YBÖ15: "Cesaretlendirilmek isterim. Kendimi daha iyi hissederim. Kendime güvenirim. İhtiyacım var. (Bilgi yarışmasına katılmak için arkadaşlarımın desteğine ihtiyacım var.)"

Benzer şekilde düşük başarılı kategorisindeki öğrencilerden de sadece biri hariç diğerleri arkadaşlarından alacakları özerklik desteğine duyduğu ihtiyacı dile getirmiştir. Aşağıda söz konusu soruya ilişkin doğrudan alıntılara yer verilmiştir.

DBÖ3: "İsterim çünkü mesela ben içimden derim ki bir şeyi yapamam, kazanamam ama arkadaşlarım yaparsın derse ben de inanırım ki yaparım."

DBÖ18: "İstemiyorum çünkü sınıftakileri sevmiyorum. Bana destek olmazlar zaten."

DBÖ21: "Çok isterim. Çok güzel hissederim yani güçlü hissederim kendimi, beni desteklerlerse." 


\section{Okulda Algılanan Arkadaş Özerklik Desteği}

Bu kategori "Okulda kendi kararlarını alırken ne kadar özgürsün? Arkadaşların okulla ilgili konularda özgür ve kendi tercihlerine göre kararlar alabilmeni destekler mi?" sorusuna verilen cevaplardan oluşmaktadır. Bu soru için hazırlanan örnek olaylar, öğrencilerin kendine ait kararları alırken arkadaşlarından destek alıp almadıkları üzerine yoğunlaşmıştır. Yüksek başarılı kategorisinde görüşülen 44 öğrenciden 29'u kendi kararlarını kendilerinin aldığını bunun için arkadaşlarından hatırı sayılır bir destek almadığını ya da onlardan etkilenmediğini dile getirmiştir. Diğer öğrenciler ise arkadaşlarının kararlarını sürekli etkilemeye çalıştı̆̆ını ve çoğu zaman bunu başardığını dile getirmiştir. Örnek olaylar ne kadar çeşitlendirilirse çeşitlendirilsin öğrencilerin özerklik desteği kavramını ya da olayını "etkilenmek, karışmak, taraf/tar olmak" şeklinde anladıkları gözlenmiştir. Bu durum, öğrencilerin özerkliğin desteklenmesi halini yaşamadıkları ve böyle bir duyguya yabancı oldukları şeklinde yorumlanmıştır. Aşağıda söz konusu soruya ilişkin doğrudan alıntılara yer verilmiştir.

YBÖ13: "Kendi kararlarımı kendim veririm. Kendi istediğimi yaparım. Arkadaşlarım beni bazen zorlar (kiminle oynayacağım konusunda); ama kendi dediğim olur."

YBÖ14: “Arkadaşlarımla ortak bir çözüm bulurum. Arkadaşlarım rahat bırakmazlar (onların istediği kişiyle oynamazsam), kendi dediklerini yaptırmaya çalışırlar."

YBÖ18: "Kendi istediğimi yaparım, arkadaşlarım saygl gösterir. İstediğim kişiyle oynarım. (Teneffüste arkadaş seçiminde)"

Düşük başarılı kategorisindeki okullarda görüşülen 44 öğrenciden 35'i arkadaşlarının istekleri ve söylemleri doğrultusunda karar aldıklarını belirtirken, 7 öğrenci kararlarını arkadaşlarıyla ortaklaşa aldığını ve 2 öğrenci de kendi kararlarını kendilerinin aldığını belirtmişlerdir. Aşağıda okulda hissedilen özerkliğe ilişkin soruya verilen cevaplardan alıntılara yer verilmiştir.

DBÖ9: “Oyun oynarken Ali'nin söylediklerinden oynuyoruz. Ben (kendi istediğim) top oynamak isterim; ama o usrar eder bana. Ben de (onun istediği) saklambaç oynarım. Çünkü onu üzmek istemem."

DBÖ12: "Oyunlara arkadaşlarımla birlikte karar veririz. Ben bazen başka bir oyun oynamak istiyorum gülüyorlar bana. Utanıyorum aslında. Sonra onlarla oynuyorum ben de." 
DBÖ15: "Ben istediğim oyunu oynuyorum. Hep birlikte oynayınca kavga ediyoruz. Ondan tek başıma sevdiğim oyunları oynarım."

\section{Arkadaşıların "Başkası Olma, Kendin Ol” Desteği}

$\mathrm{Bu}$ kategoride "Arkadaşların seni kendin olman için cesaretlendirir mi?” sorusuna verilen cevaplar yer almaktadır. Öğrencilerin başkası gibi değil kendi gibi olup olmadığı, okul ile ilgili konularda karar alırken özgür ve özgün olup olmadığ 1 ve bu tercihleri arkadaşlarının destekleme ya da değiştirmeye çalışma durumu üzerine yoğunlaşılmıştır. Söz konusu soru, örnek olaylar ve birçok sonda soru kullanılmasına rağmen öğrencilerin büyük çoğunluğu tarafindan net bir şekilde anlaşılamamış, verilen cevaplar arkadaşlarının kendilerine karışıp karışmaması noktasında takılıp kalmıştır. Ancak araştırmacılar tarafından yapılan çıkarımlarda öğrencilerin kendileri gibi olmakta güçlük çektiği, çoğu durumda yakın arkadaşlarının sempatisi kazanmak için ya da arkadaşlarını sevdikleri için onlar gibi davranma eğilimi dikkati çekmiştir. Bu durum düşük başarılı öğrencilerde çok daha baskındır.

Yüksek başarılı kategorisindeki okullarda görüşülen 44 öğrenciden 20'si arkadaşlarının kendi kararlarına karışmayacağını ifade ederken, 8'i arkadaşlarının kendi kararlarına karışacağını fakat etkilenmeyeceğini 2'si de arkadaşlarının kendilerine kararları konusunda karışacağını ve onların da arkadaşlarından etkileneceğini belirtmiştir. Aşağıda söz konusu soruya verilen cevaplardan alıntılara yer verilmiştir.

YBÖ3: "Hangi gruba gideceğime (bir etkinlik için grup seçerken) kolay gelen, işime geldiği gibi seçerim. Arkadaşlarım kararımı etkilemeye çalışır, benim grubuma gel der; ama benim dediğim olur."

YBÖ4: "Hangisini yapacağıma inanırsam (bir etkinlik için grup seçerken) ona katılırım. Arkadaşlarım bana karışmazlar. En iyi arkadaşım farklı grupta da olsa beni destekler. Onu seviyorum."

YBÖ17: "En yakın arkadaşımın grubuna giderim (arkadaşımla farklı gruplarda olduğumda). Farkl gruba gidersem arkadaşım gel der, ben de yaparım."

YBÖ31: "Yani kendin olmak ne demek? Bir şey anlamadım. Arkadaşım başka kulübe gitsem karışmaz. Ben de onlara karışmam. Ama ... benimle olsa isterim. Konuyu ben okurum. Ama bazen ... gibi konuşurken elimi ağzıma götürürüm, herkes güler. O zaman taklit yaparım kendim olmuyorum yani. Böyle bir şey mi?" 
YBÖ32: "Ben utanırım, kendim istediğim gibi olursam dalga geçerler. Mertcan "Çocuksun sen!" diye benimle dalga geçer. Bazen de "Bebek gibi koşma!" der. Öğretmene desem "Mızıkçı!" der, dalga geçer."

Düşük başarılı kategorisindeki okullarda görüşülen 44 öğrenciden 4'ü arkadaşlarının kendi kararlarına karışmayacağını ifade ederken, 8'i arkadaşlarının kendi kararlarına karışacağını fakat arkadaşlarından etkilenmeyeceğini, 32'si de arkadaşlarının kendine kararları konusunda karışacağını ve arkadaşlarından etkileneceğini belirtmiştir.

DBÖ6: "En sevdiğim arkadaşlarım hangi gruptaysa oraya giderim. Çünkü gittiğim grup arkadaşlarımla güzel olur. Ben tek başıma olmayı hiç istemem. Sevdiğim arkadaşlarım olmazsa yalnız kalırım. Onlar grubumu değişmemi isterse değişirim."

DBÖ23: "Benim girmek istediğim gruba arkadaşlarım karlşır. İstediğim gruba girmeme karışsalar da ben kendi grubumda kalırım."

DBÖ30: "En yakın arkadaşım bana karışır. Bana der ki benim olduğum gruba gel. Ben de değiştirim grubumu. Çünkü arkadaşımı seviyorum bana küssün istemem."

\section{Arkadaşların "Farklı Düşünsek de Saygı Duyuyorum." Desteği}

$\mathrm{Bu}$ kategori “Arkadaşların, duygu ve düşüncelerin kendilerininkinden farklı olsa bile senin duygu ve düşüncelerini kabul edip saygı duyar mı?” sorusuna verilen cevaplardan oluşmaktadır. Bu soru için hazırlanan örnek olaylar, öğrencilerin duygu ve düşünceleri arkadaşlarının duygu ve düşüncelerinden farklılaştığında arkadaşlarının bu durumu kabul edip etmemesi ve saygı duyma durumu üzerinde yoğunlaşmıştır. Yüksek başarılı okullarda görüşülen 44 öğrenciden 33'ü arkadaşlarının kendi duygu ve düşüncelerini kabul edip saygı duyduğunu, 4'ü arkadaşlarının kendi duygu ve düşüncelerini kabul etmeyip saygı duymadığını, 7'si ise kabul etme ve saygı duyma durumunun bazen değiştiğini belirtmiştir. Aşağıda söz konusu soruya verilen cevaplar, öğrencilerin kendi ifadeleriyle aynen verilmiştir.

YBÖ1: "Bana saygl duyarlar (arkadaşlarımla farklı fikirde olduğumda), kızmazlar. Ortak karar alırız. Arkadaşlarım fikirlerime saygı duyar."

YBÖ9: "Farklı fikirlerde (arkadaşlarımla farklı düşündüğümüzde) kestirip atar, düşüncelerimi dinlemez.” 
YBÖ13: "Bazen benim düşüncelerimi dinlerler(arkadaşlarım). Benim dediklerimi her zaman dinlemezler."

Düşük başarılı okullarda ise durum tam tersidir. Görüşülen 44 öğrenciden 6'sı arkadaşlarının kendi duygu ve düşüncelerini kabul edip saygı duyduğunu, 33'ü arkadaşlarının kendi duygu ve düşüncelerini kabul etmeyip saygı duymadığını, 5'i ise kabul etme ve saygı duyma durumunun duruma göre değiştiğini belirtmiştir.

DBÖ5: "Saygı verirler mi bilmiyorum. Bazen ben bir şey söylediğimde beğeniyorlar ama bazen de dalga geçiyorlar. Beni dışlarlar bence saygı vermezler. Yine de bilmiyorum bazen beni seviyorlar, dinliyorlar."

DBÖ17: "Ben eğer farklı bir şey dersem arkadaşım tamam, der. Bence saygl gösterir. Çünkü benim sözümü dinlerler."

DBÖ28: "Biz farklı şeyler düşündügümüzde ben genelde susuyorum. Arkadaşlarım karar veriyor. Çünkü benim dediklerimi beğenmiyorlar. Kabul etmiyorlar."

\section{5. Öğretmen görüşleri}

Çalışma kapsamında her iki kategorideki öğrencilerin sınıf öğretmenleriyle akran özerklik desteği üzerine görüşülmüştür. Öğretmenlere yöneltilen soruda öğrencilerin sınıf içerisinde birbirlerine özerklik desteği verip vermediği sorulmuştur. Yüksek başarılı okullardaki sınıf öğretmenlerinden biri öğrencilerin pek çoğunun birbirlerini desteklediklerini söylemiştir.

"Öğrencilerimin pek çoğu hemen her konuda birbirlerini destekler. Kendi içlerinde dayanışma sağlayarak birbirlerinin eksiklerini tamamlamaya çalışır. Mesela sinufta çok çekingen olan bir öğrenciye çoğu arkadaşı bu çekingenliği bırakmazsa futbolcu olamayacağını söyleyerek bu durumdan kurtarmaya çalışlyorlar. Ödevini yapmayan ögrencilerin ödevlerini yapmast için yardımcı oluyorlar yapmazsan bir daha beden dersinde seninle oynamam diyorlar ya da çok konuşan ögrencilere kendi içinde vazgeçmesi için konuşursan küserim diyorlar. Yani öğrenciler arkadaşlarının özellikle en yakın arkadaşların olumsuz bir durumdan kurtarmak için veya ögretmen kizmasin diye hemen kendilerince bir çözüm bulmaya çallşlyorlar. Böyle öğrenciler olmasına ră̆men sayıları az da olsa arkadaşların sürekli şikâyet ederek ceza almalarını isteyen, onların kötü not almasına sevinen ögrenciler de mevcut." (Öğretmen YB1)

Düşük başarılı öğrencilerin sınıf öğretmenleriyle yapılan görüşme so- 
nucunda öğrencilerin birbirine özerklik desteği vermediği bulgusuna ulaş1mıştır. Bu öğretmenlerden "Öğretmen DB2" kod adlı biri, öğrencilerin genelde birbirlerine ödev, sunum vb. konularda destek vermediğini, tam tersi şekilde "Sen bunu beceremezsin ki", "Yapsan da hiç güzel olmayacak" gibi cümlelerle birbirlerine ket vurduğunu belirtmiştir. Görüşme yapılan öğretmen özellikle öğrencilerden biri daha önce hiç söylenmedik ve öğrencilerin yeni duyduğu bir şey anlattığında veya yaptığında diğerlerinin kıskançlık göstererek arkadaşlarına inanmadığını ve yaptığı şeyin güzel olmadığını söylediklerini belirtmiştir. Sınıfta öğrencilerin birbirlerini desteklemeleri konusunda kendisinin de çok sıkıntı çektiğini ve çocukların birbirlerini dersle ilgili konularda desteklemediğini söylemiştir.

\section{6. Öğrenci Resimleri}

Çalışmanın amacı doğrultusunda öğrencilerden arkadaşlarından aldıkları ya da almadıklarını düşündükleri özerklik desteğine ilişkin resim çizmeleri istenmiştir. Yüksek başarılı gruptaki öğrencilerden 12 'si resim yapmak konusunda istekli olmuştur. Bu öğrencilerden biri böyle bir desteği hissetmediğini belirtmiş resmi de bu doğrultuda çizmiştir. Kalan 11 öğrenci ise arkadaşlarının kendilerini desteklediğini vurgulayan resimler yapmıştır. Ancak resimler incelendiğinde öğrencilerin özerklik desteği diye anlatmaya çalıştıkları şeyin aslında "taraf olmak, yan tutmak, yanında olmak" anlamında bir destek olduğu anlaşılmıştır. Ayrıca çizilen resimlerin tamamının "yarış ve yarışmak" üzerinde yoğunlaştığı dikkat çekmiştir. Öğrencilerin resimleri bu şekilde çizmelerinde, araştırmacıların görüşmeler sırasında kullandığı örnek olayların etkili olmuş olabileceği düşünülmektedir. Düşük başarılı gruptaki öğrencilerin hiçbiri resim çizmek istememiştir. Şekil 1, Şekil 2, Şekil 3 ve Şekil 4'te örnek olması bakımından seçilen resimlerden dördü gösterilmektedir. Şekil 5 yüksek başarılı grupta olup arkadaşlarından herhangi bir destek hissetmediğini ifade eden öğrenciye aittir. 


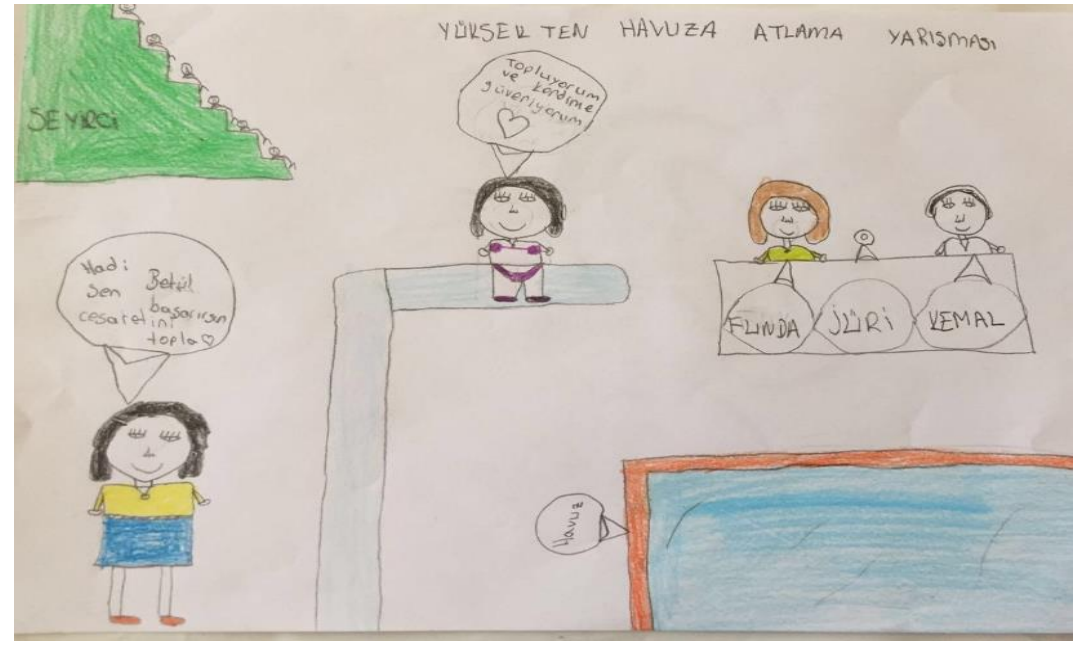

Şekil 1. Arkadaş özerklik desteği hisseden öğrencinin resmi.

Şekil 1'deki resimde öğrencinin kendini yüksekten havuza atlama yarışmasında resmettiği görülmektedir. Arkadaşlarından biri, onu "Haydi Betül, sen başarırsın, cesaretini topla." diyerek cesaretlendirmektedir.

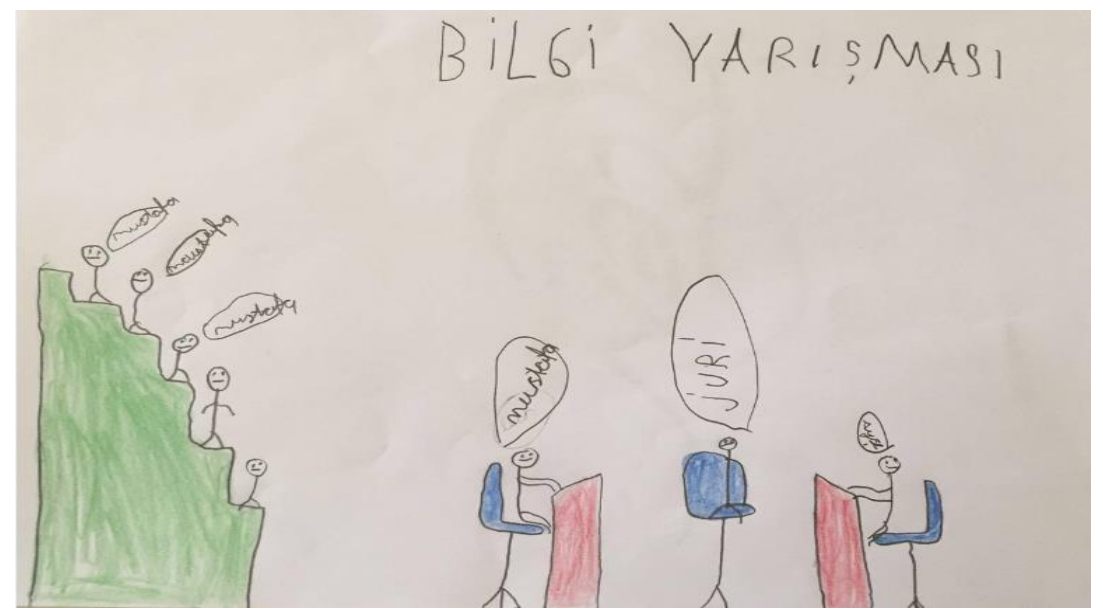

Şekil 2. Arkadaş özerklik desteği hisseden öğrencinin resmi.

Şekil 2'deki resimde öğrenci kendini bilgi yarışmasında resmetmiş̧ir ve onu izleyen arkadaşlarının hepsi hep bir ağızdan "Mustafa" diye tezahürat yaparak onu desteklemektedir. Bu öğrencinin özerklik desteğini, “destek, yan, yandaş, arka olmak" kavramıyla karıştırmış olabileceği düşünülmekle beraber özerklik desteğinin bu kavramları da içerdiği hesaba katıldığında öğrencinin 
bu hissi yaşadığı ya da yaşıyor olduğu söylenebilir.

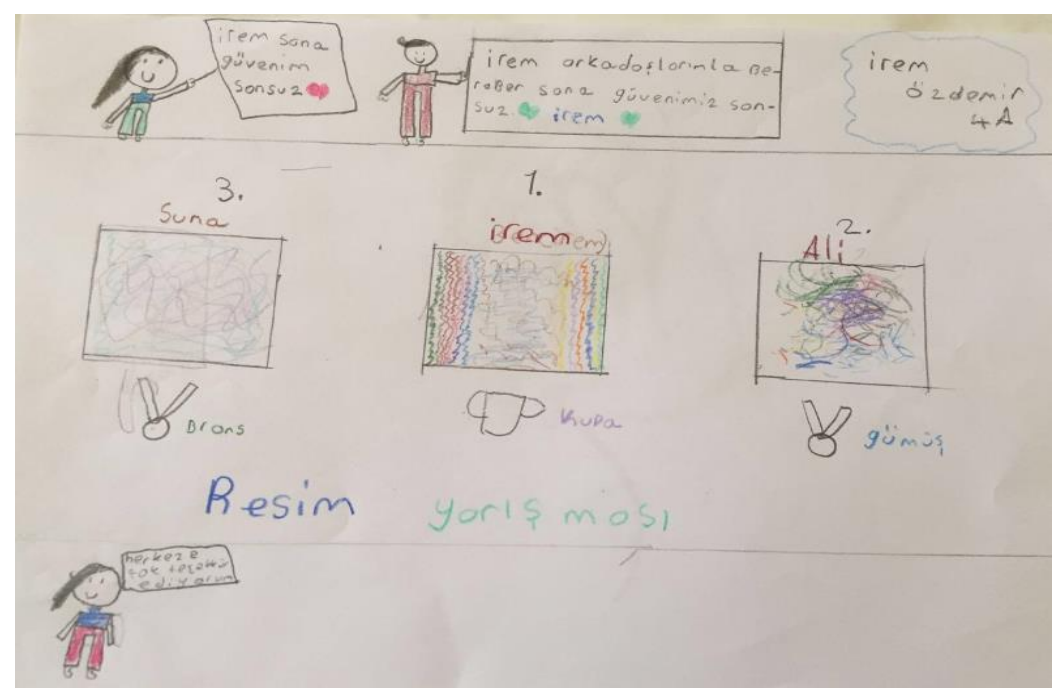

Şekil 3. Arkadaş özerklik desteği hisseden öğrencinin resmi.

Şekil 3’te öğrencinin kendini yine bir yarışmada hayal ettiği görülmektedir. Arkadaşlarından biri ona hitaben "Irem, sana güvenim sonsuz." derken, diğeri "İem, arkadaşlarımla beraber sana güvenimiz sonsuz." demektedir. Resimden, bu desteği alan öğrencinin yarışmayı birincilikle tamamladığı anlaşılmaktadır.

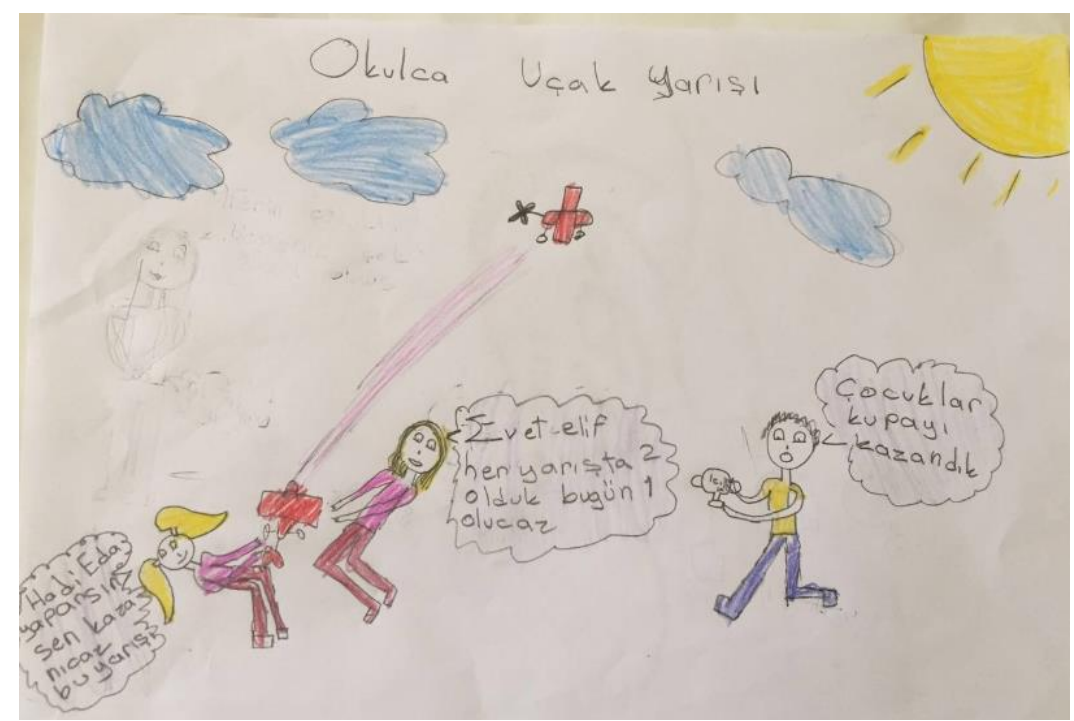

Şekil 4. Arkadaş özerklik desteği hisseden öğrencinin resmi. 
Şekil 4'te ise diğer resimlerle benzer şekilde yine bir yarışma, fakat diğerlerinden farklı olarak, grup işbirliğinin önemli olduğu bir ekip yarışması dikkati çekmektedir. Resimde arkadaşların birbirini cesaretlendirici sözlerle desteklemesi anlatılmaktadır. Resimden, bu desteği alan öğrencinin yarışmayı "Çocuklar kupayı kazandık." sözleriyle ilan ettiği ve dolayısıyla kazandığı anlaşılmaktadır.

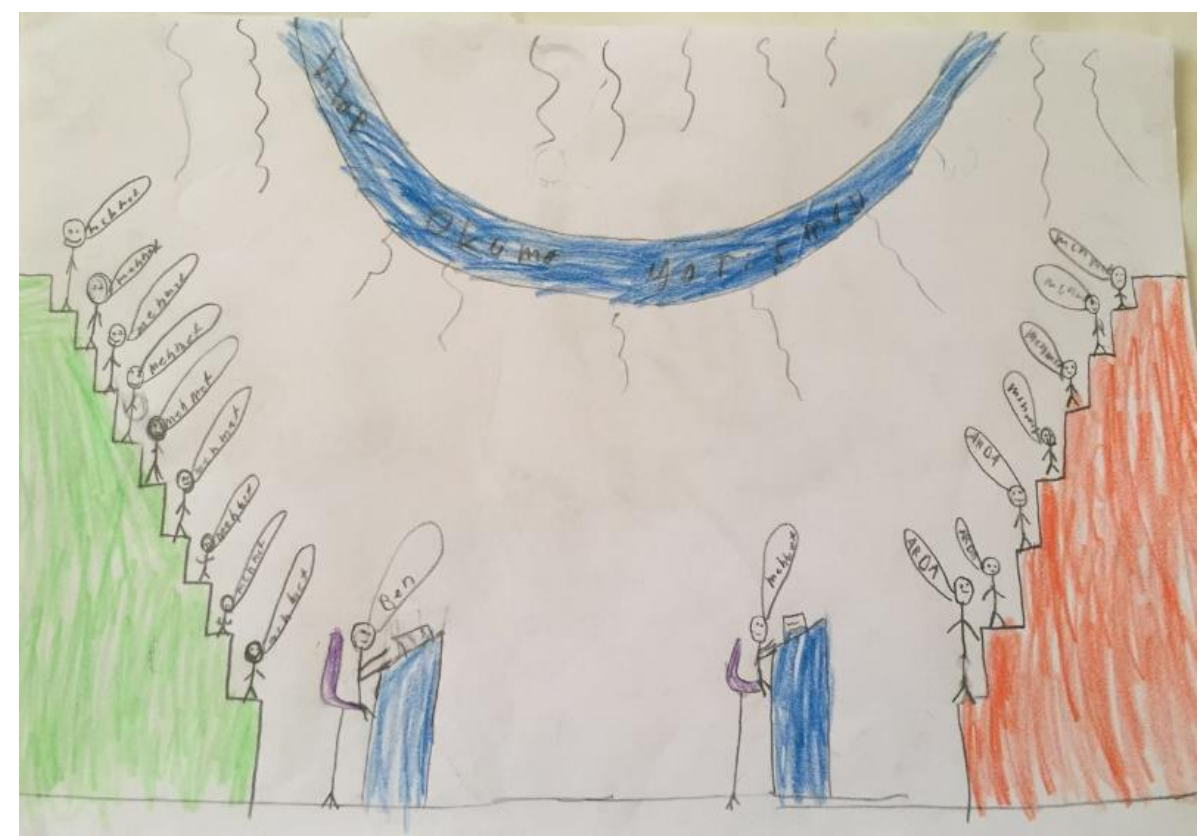

Şekil 5. Arkadaş özerklik desteği hissetmeyen öğrencinin resmi.

Şekil 5'te ise bir kitap okuma yarışması resmedilmiştir ve öğrenci bu yarışta kendine "ben" diyerek işaret etmiştir. Resimde öğrencinin hemen arkasında duran arkadaşlarının karşı taraftaki Mehmet isimli öğrenciyi desteklediği, benzer şekilde Mehmet isimli öğrencinin arkasındakilerden de çok azının resmi yapan öğrenciyi desteklediği görülmektedir. Bu öğrenciyle resim hakkında konuşulduğunda "Bu durum gerçekte de böyle. Beni destekleyen kişi çok azdır. Arkadaşlarımdan böyle bir desteği hissetmiyorum." ifadelerini kullanmıştır.

\section{Sonuç, Tartışma ve Öneriler}

Yakın arkadaşlık ilişkileri kurmak ve sürdürmek, insan hayatının en önemli ve özerk olarak sürdürülen unsurlarındandır (Deci ve Ryan, 2014). Ar- 
kadaş özerklik desteğinin önemine dikkat çekilmek istenen bu çalışmada ilkokul dördüncü sınıf öğrencileriyle çalışılmıştır. Araştırma sorularıyla direkt olarak tespit edilmese de araştırmacıların bu çalışma yoluyla dolaylı olarak gözlemlediği önemli bir sonuç, ülkemizde arkadaşların özerklik destekleyiciliği konusunun özellikle ilkokul çocukları arasında ihmal ediliyor olduğudur.

Yurt dışında yapılan çalışmalar, genellikle adolesanlardaki özerklik destekleyiciliğine odaklanmış olmasına rağmen konuyu çocuklar bağlamında inceleyen çalışmalar da mevcuttur. Bu çalışmalardan birinde akran ve öğretmen desteğinin çocukların toplum içindeki öz saygılarına etkisi incelenmiştir (Spilt, Lier, Leflot, Onghena ve Colpin, 2014). Sonuçlar, akran reddinin çocukların sosyal öz saygısını engellediğini ve bunun da aidiyet gelişimini olumsuz etkilediğini ortaya koymuştur.

$\mathrm{Bu}$ çalışma kapsamında, gerek düşük düzeyde başarılı gerekse yüksek düzeyde başarılı öğrencilerin tamamına yakını, arkadaşları tarafından verilecek özerklik desteğini arzu ettiklerini, böyle bir desteğin hoşlarına gideceğini vurgulamıştır. Bulgulara göre yüksek başarılı öğrencilerin büyük çoğunluğu, okulda kendi kararlarını kendi almak noktasında kendini özgür hissederken bu konuda arkadaşlarından yeterince destek alamamaktadır. Özerklik hissetme durumu düşük başarılı öğrencilerde tam tersidir. Bu öğrencilerin yarıdan fazlası okulda özerkliği hissetmemekte ve kararlarında arkadaşlarının etkisi görülmektedir. Bu bulgu, öğrenciler arkadaşlarından yeterince özerklik desteği alamasa da özerklik hissetme durumunun, yüksek başarılı öğrencilerin lehine başarı düzeyiyle ilişkili olabileceği şeklinde yorumlanabilir.

Bulgular öğrencilerin kendileri gibi olmakta güçlük çektiği, kendi gibi olmakla ilgili pekiştirilmediği, hatta böyle bir durumun varlığından bile habersiz olduğu sonucunu ortaya çıkarmıştır. Öğrenciler çoğu durumda yakın arkadaşlarının sempatisi kazanmak ya da arkadaşlarını sevdikleri için onlar gibi davranma eğilimindedirler. Bu durum düşük başarılı öğrencilerde çok daha baskındır. Yüksek başarılı kategorisindeki okullarda görüşülen öğrencilerin yarıya yakınının arkadaşları tarafından herhangi bir müdahaleyle karşılaşmadığı ve dolayısıyla kendisi gibi olmak noktasında yeterli olmamakla birlikte daha özgür olduğu anlaşılmaktadır. Düşük başarılı kategorisindeki okullarda ise görüşülen öğrencilerin büyük çoğunluğu arkadaşlarının güdümünde olduğu ve dolayısıyla özgün olmak noktasında yetersiz olduğu anlaşılmaktadir. 
Benzer şekilde bulgular yüksek başarılı okullarda öğrenim gören dördüncü sınıf öğrencilerinin duygu ve düşüncelerinin büyük oranda arkadaşları tarafindan kabul görüp saygı duyulduğunu göstermektedir. Düşük başarılı okullardaki öğrenciler böyle bir saygı duyulma halini çok daha az yaşamaktadir.

Görüşülen öğretmenler de öğrencilerin söylediklerini destekler ifadeler kullanmıştır. Özellikle düşük başarılı okullarda özerklik desteği yok denecek kadar azdır.

Sonuç olarak, gerek başarılı öğrenciler gerekse akademik başarı açısından geride kalan öğrencilerin, arkadaşları tarafından özerkliğinin desteklenmesi ve teşvik edilmesi duygusunu arzu edilen ölçüde yaşamadığı tespit edilmiştir. Bu durum ülkemizde gerek çocuklarda gerekse öğretmenlerde "arkadaş özerklik destekleyiciliğı”yle ilgili bir farkındalık olmadığı şeklinde yorumlanabilir. Yüksek başarılı öğrenciler özerklik desteğini kısmen de olsa hissettiğini belirtmiş olmasına rağmen bu başarı, iyi olma, yüksek motivasyon gibi birçok olumlu çıktıyla eşleştirilen özerklik desteği için yeterli görülmemektedir. Bu sonuçlar ışığında şu öneriler teklif edilmektedir:

1. Eğitim ve öğretimin temel olarak okullarda sürdürüldüğg̈ göz önünde bulundurulduğunda özerkliğin öğrencilere hissettirilmesi noktasında sınıf içinde yapılan uygulamalar önemlidir. Öğrenci merkezli sınıf ortamı oluşturmak ve öğrencinin kendi öğrenmesinde söz sahibi olabilmesi için yapılacak işlerden ilki, öğrencilerin planlama, öğrenme süreci ve değerlendirme boyutlarında karar verme mekanizmasının içinde yer almasına firsat vermektir.

2. Arkadaşların birbirlerinin akademik özerkliğini desteklemesi noktasında öğretmenler öğrencilere yol göstermeli, özerklik destekleyici tutumu teşvik edici tutum ve davranışlarda bulunmalıdır.

\section{Kaynakça}

Asher, S. R. ve Parker, J. G. (1989). Significance of peer relationship problems in childhood. Social Competence in Developmental Perspective, 51, 5-23.

Baard, P. P., Deci, E. L. ve Ryan, R. M. (2004). Intrinsic need satisfaction: A motivational basis of performance and well-being in two work settings. Journal of Applied Social Psychology, 34, 2045-2068.

Bacanlı, H. (1999). Sosyal beceri eğitimi. Ankara: Nobel Yayın Dağıtım. 
Bagwell, C. L., Newcomb, A. F. ve Bukowski, W. M. (1998). Preadolescent friendship and peer rejection as predictors of adult adjustment. Child Development, 69, 140-153.

Buhs, E. S., Ladd, G. W. ve Herald, S. L. (2006). Peer exclusion and victimization: Processes that mediate the relation between peer group rejection and children's classroom engagement and achievement? Journal of Educational Psychology, 98(1), 1-13.

Deci, E. L., Ryan, R. M., Gagné, M., Leone, D. R., Usunov, J. ve Korazheva, B. P. (2001). Need satisfaction, motivation, and wellbeing in the work organizations of a former Eastern Bloc country. Personality and Social Psychology Bulletin, 27, 930-942.

Deci, E. L., La Guardia, J. G., Moller, A. C., Scheiner, M. J. ve Ryan, R. M. (2006). On the benefits of giving as well as receiving autonomy support: Mutuality in close friendships. Personality and Social Psychology Bulletin, 32, 313-327.

Deci, R. ve Ryan, R. M. (2014). Autonomy and need satisfaction in close relationships: Relationships motivation theory. N. Weinstein, (Ed.), human motivation and interpersonal relationships içinde (53-73). New York: Springer Netherlands, Springer Science+Business Media Dordrecht.

DeRosier, M. E., Kupersmidt, J. B. ve Patterson, C. J. (1994). Children's academic and behavioral adjustment as a function of the chronicity and proximity of peer rejection. Child Development, 65(6), 1799-1813.

Doeselaar, C. Van. (2015). The role of best friends' autonomy support and identity in adolescents' educational identity formation. Yayınlanmamış yüksek lisans tezi, Utrecht University Faculty of Social and Behavioural Sciences.

Giessen, D. V., Branje, S. ve Meeus, W. (2014). Perceived autonomy support from parents and best friends: Longitudinal associations with adolescents' depressive symptoms. Social Development, 23(3), 537-555.

Gülay, H. (2009). Okul öncesi dönemde akran ilişkileri. Ankara: PegemA Yayincilik.

Hodgins, H. S., Koestner, R. ve Duncan, N. (1996). On the compatibility of 
autonomy and relatedness. Personality and Social Psychology Bulletin, 22, 227-237.

Hymel, S., Rubin, K. H., Rowden, L. ve LeMare, L. (1990). Children's peer relationships: Longitudinal prediction of internalizing and externalizing problems from middle childhood. Child Development, 61, 2004-2021.

Kochenderfer, B. J. ve Ladd, G. W. (1996). Peer victimization: Cause or consequence of children's school adjustment difficulties? Child Development, 67, 1293-1305.

Kochenderfer, B. J. ve Ladd, G. W. (1996). Peer victimization: Cause or consequence of children's school adjustment difficulties? Child Development, 67, 1293-1305.

La Guardia, J. G., Ryan, R. M., Couchman, C. E. ve Deci, E. L. (2000). Within-person variation in security of attachment: A self-determination theory perspective on attachment, need fulfillment, and well-being. $J_{o-}$ urnal of Personality and Social Psychology, 79, 367-384.

Ladd, G. W. (1990). Having friends, keeping friends, making friends, and being liked by peers in the classroom: Predictors of children's early school adjustment. Child Development, 61(4), 1081-1100.

Ladd, G. W., Kochenderfer, B. J. ve Coleman, C. C. (1996). Friendship quality as a predictor of young children's early school adjustment. Child Development, 67, 1103-1118.

Ladd, G. W., Herald, S. L. ve Andrews, R. K. (2006). Young children's peer relations and social competence. B. Spodek ve O. N. Saracho, (Ed.), Handbook on the education of young children içinde (23-54). Hillsdale, NJ: Erlbaum.

Maslow, A. H. (1970). Motivation and personality. NewYork: Harper and Row.

Parker, J. G. ve Asher, S. R. (1993). Friendship and friendship quality in middle childhood: Links with peer group acceptance and feelings of loneliness and social dissatisfaction. Developmental Psychology, 29, 611621.

Parker, J. G., Rubin, K. H., Price, J. M. ve DeRosier, M. E. (1995). Peer rela- 
tionships, child development, and adjustment: A developmental psychopathology perspective. D. Cicchetti, ve D. J. Cohen, (Ed.), Developmental Psychopathology: Risk, Disorder, and Adaptation (Vol. 2) içinde (96-161). New York: Wiley.

Piaget, J. (1932). The moral judgment of the child. https://archive.org/details/moraljudgmentoft005613mbp

Rodkin, P. C. ve Hodges, E. V. E. (2003). Bullies and victims in the peer ecology: Four questions for psychologists and school professionals. School Psychology Review, 32(3), 384-400.

Rohrbeck, C. A. (2003). Peer relationships, childhood. T. P. Gullotta, M. Bloom, J. Kotch, C. Blakely, L. Bond, G. Adams, C. Browne, W. Klein ve J. Ramos, (Ed.), Encyclopedia of primary prevention and health promotion içinde (804-808). New York: Klower Academic.

Ruzek, E. A., Hafen, C. A., Allen, J. P., Gregory, A., Mikami, A. Y. ve Pianta, R. C. (2016). How teacher emotional support motivates students: The mediating roles of perceived peer relatedness, autonomy support, and competence. Learning and instruction, 42, 95-103.

Soenens, B., Vansteenkiste, M., Goossens, L., Duriez, B. ve Niemiec, C. P. (2008). The intervening role of relational aggression between psychological control and friendship quality. Social Development, 17, 661681.

Song, S. Y. (2006). The role of protective peers and positive peer relationships in scholl bullying: How can peers help? Yayınlanmamış doktora tezi, University of Nebraska.

Spilt, J. L., Lier, P. A., Leflot, G., Onghena, P. ve Colpin, H. (2014). Children's social self-concept and internalizing problems: The influence of peers and teachers. Child development, 85(3), 1248-1256.

Sullivan, H. S. (1997). The interpersonal theory psychiatry. W. W. Norton \& Company: Newyork

Wentzel, K. R. ve Asher, S. R. (1995). The academic lives of neglected, rejected, popular, and controversial children. Child Development, 66, 754-763.

Williams, G. C., Grow, V. M., Freedman, Z. R., Ryan, R. M. ve Deci, E. L. 
(1996). Motivational predictors of weight loss and weightloss maintenance. Journal of Personality and Social Psychology, 70, 115-126. 